\title{
Correction to: Electrosprayed catalyst layers based on graphene-carbon black hybrids for the next-generation fuel cell electrodes
}

\author{
Lale Işıkel Şanlı ${ }^{1}$, Begüm Yarar $^{2}$, Vildan Bayram²${ }^{2}$, and Selmiye Alkan Gürsel ${ }^{1,2, *}$ \\ ${ }^{1}$ Sabanci University Nanotechnology Research and Application Center (SUNUM), Sabanci University, Istanbul 34956, Turkey \\ ${ }^{2}$ Faculty of Natural Science and Engineering, Sabanci University, Istanbul 34956, Turkey
}

Published online:

17 July 2018

(C) The Author(s) 2018

\section{Correction to:}

J Mater Sci (2017) 52:2091-2102 https://doi.org/10.1007/s10853-016-0497-0

The article "Electrosprayed catalyst layers based on graphene-carbon black hybrids for the next-generation fuel cell electrodes," written by Lale Işıkel Şanlı, Begüm Yarar, Vildan Bayram, and Selmiye Alkan Gürsel, was originally published electronically on the publisher's internet portal (currently SpringerLink) on October 25, 2016, without open access.
The original article can be found online at https:/ / doi.org/10.1007/s10853-016-0497-0.

Address correspondence to E-mail: selmiye@sabanciuniv.edu
With the author(s)' decision to opt for Open Choice the copyright of the article changed on July 16, 2018, to (C) The Author(s) 2016 and the article is forthwith distributed under the terms of the Creative Commons Attribution 4.0 International License (http://creati vecommons.org/licenses/by/4.0/), which permits use, duplication, adaptation, distribution and reproduction in any medium or format, as long as you give appropriate credit to the original author(s) and the source, provide a link to the Creative Commons license and indicate if changes were made. 